\title{
Collection of tracheal aspirate: safety and microbiological concordance between two techniques*
}

\author{
COLHEITA DE ASPIRADO TRAQUEAL: SEGURANÇA E CONCORDÂNCIA \\ MICROBIOLÓGICA ENTRE DUAS TÉCNICAS
}

\author{
RECOLECCIÓN DE ASPIRADO TRAQUEAL: SEGURIDAD Y CONCORDANCIA \\ MICROBIOLÓGICA ENTRE DOS TÉCNICAS
}

\author{
Oleci Pereira Frota ${ }^{1}$, Adriano Menis Ferreira ${ }^{2}$, Larissa da Silva Barcelos ${ }^{3}$, Evandro Watanabe ${ }^{4}$, \\ Nádia Cristina Pereira Carvalho ${ }^{5}$, Marcelo Alessandro Rigotti ${ }^{6}$
}

\begin{abstract}
Objective: To evaluate the safety of the performance of the traditional and protected collection techniques of tracheal aspirate and to identify qualitative and quantitative agreement of the results of microbiological cultures between the techniques. Method: Clinical, prospective, comparative, singleblind research. The sample was composed of 54 patients of $\geq 18$ years of age, undergoing invasive mechanical ventilation for a period of $\geq 48$ hours and with suspected Ventilator Associated Pneumonia. The two techniques were implemented in the same patient, one immediately after the other, with an order of random execution, according to randomization by specialized software. Results: No significant events occurred oxygen desaturation, hemodynamic instability or tracheobronchial hemorrhage $(p<0.05)$ and, although there were differences in some strains, there was qualitative and quantitative agreement between the techniques $(p<0.001)$. Conclusion: Utilization of the protected technique provided no advantage over the traditional and execution of both techniques was safe for the patient.
\end{abstract}

\section{DESCRIPTORS}

Pneumonia, ventilator-associated

Culture techniques

Infection

Intensive care

Nursing care

Patient's safety

\section{RESUMO}

Objetivo: Avaliar a segurança da execução das técnicas tradicional e protegida de coIheita de aspirado traqueal e identificar a concordância qualitativa e quantitativa dos resultados de culturas microbiológicas entre as técnicas. Método: Pesquisa clínica, prospectiva, comparativa, simples-cega. A amostra foi constituída de 54 pacientes com idade $\geq 18$ anos, submetidos à ventilação mecânica invasiva por período $\geq 48$ horas e com suspeita de Pneumonia Associada à Ventilação Mecânica. As duas técnicas foram implementadas no mesmo paciente, uma imediatamente seguida da outra, sendo a ordem de execução aleatória, segundo randomização por software especializado. Resultados: Não ocorreram eventos significativos de queda da saturação de oxigênio, instabilidade hemodinâmica e hemorragias traqueobrônquicas $(p<0,05)$ e, embora tenham ocorrido divergências em algumas cepas, houve concordância qualitativa e quantitativa entre as técnicas $(p<0,001)$. Conclusão: A utilização da técnica protegida não proporciona vantagem em detrimento da tradicional e a execução de ambas as técnicas foi segura para o paciente.

DESCRITORES
Pneumonia associada à ventilação mecânica
Técnicas de cultura
Infecção
Terapia intensiva
Cuidados de enfermagem
Segurança do paciente

\section{RESUMEN}

Objetivo: Evaluar la seguridad de la ejecución de las técnicas tradicional y protegida de la recolección de aspirado traqueal e identificar la concordancia cualitativa y cuantitativa de los resultados de los cultivos microbiológicos entre estas técnicas. Método: Investigación clínica, prospectiva, comparativa, ciega simple. La muestra fue constituida por 54 pacientes mayores de 18 años que fueron sometidos a ventilación mecánica invasiva durante 48 horas o más y con sospecha de Neumonía Asociada a la Ventilación Mecánica. Las dos técnicas fueron implementadas en el mismo paciente, una inmediatamente posterior a la otra. El orden de ejecución de las técnicas fue aleatorio, hecho por un software especializado. Resultados: No hubo eventos significativos en la disminución de la saturación de oxígeno, inestabilidad hemodinámica y hemorragias traqueo bronquiales $(p<0,05)$ y aunque ocurrieron diferencias en algunas cepas, hubo concordancia cualitativa y cuantitativa entre las técnicas $(p<0,001)$. Conclusión: El uso de la técnica protegida no ofrece ninguna ventaja sobre la técnica tradicional y la aplicación de ambas técnicas es segura para el paciente.

\author{
DESCRIPTORES \\ Neumonía asociada al ventilador \\ Técnicas de cultivo \\ Infección \\ Cuidados intensivos \\ Atención de enfermería \\ Seguridad del paciente
} "Extracted from part of the dissertation "Colheita de aspirado traqueal para o diagnóstico microbiológico de pneumonia associada à ventilação mecânica:
comparação de duas técnicas" , Program of Health and Development in the Midwest Region, Federal University of Mato Grosso do Sul, 2013 . ${ }^{1}$ Master's
from the Program of Health and Development in the Midwest Region, Federal University of Mato Grosso do Sul, Campo Grande, MS, Brazil 2 Master's and
Doctoral Advisor, Program of Health and Development in the Midwest Region and Master's in Nursing, Federal University of Mato Grosso do Sul, Campo
Grande, MS, Brazil ${ }^{3}$ Assistant professor, Nursing Course, Federal University of Mato Grosso do Sul, Coxim, MS, Brazil ${ }^{4}$ Professor, Doctor, College of
Odontology of Ribeirão Preto, University of Sao Paulo, Ribeirao Preto, SP, Brazil ${ }^{5}$ Pharmaceutical Biochemistry, Laboratory of Microbiology, University
Hospital Center, Federal University of Mato Grosso do Sul, Campo Grande, MS, Brazil ${ }^{6}$ Assistant professor, Nursing Course, Federal University of Mato
Grosso do Sul, Três Lagoas, MS, Brazil 


\section{INTRODUCTION}

Currently, the accurate diagnosis of ventilator-associated pneumonia (VAP) causes great difficulty and remains a constant challenge for clinical practice. The adequate management of patients with this type of infection is multifactorial, as it depends on a series of knowledge, practices and human, material and organizational resources. Early initiation of necessary, effective and safe antimicrobials is an integral part of this context and is integrated, in part, to the diagnostic procedures employed in institutions.

The tracheal aspirate (TA), whose collection is one of the attributions of the nurse caring for intubated patients, is a method of obtaining tracheal secretions for culture and microbiological diagnosis of VAP. It is easily performed the bedside, relatively simple, minimally invasive and inexpensive, has a proven acceptable accuracy and requires minimal investment for the training of health professionals ${ }^{(1)}$.

Some authors ${ }^{(2-3)}$ point out, however, that further evidence is required for the management of TA, especially with regard to the techniques of microbiological collection and processing of the samples, because there are different protocols and some unresolved issues. Bacterial and fungal colonization of the internal surface of the endotracheal tube (ETT) in the form of biofilm is one of the factors which contributes most to harvesting of non-representative samples, the occurrence of false results or questionable cultures with no diagnostic value, given the possibility of contamination of the sample during the collection phase.

It is believed that the biofilm, in addition to causing serious recurrent infections, acts as a reservoir for microorganisms that affects the microbiological analysis of tracheobronchial content and causes doubts in interpreting the results of cultures due to contamination, colonization and infection $^{(4)}$. Therefore, microorganisms that colonize the ETT and are not causing pneumonia, may be collected by TA by traditional technique and impair the diagnostic accuracy ${ }^{(5)}$.

Accordingly, since the infection occurs in the pulmonary parenchyma and not in the ETT, it was inferred that the procurement of tracheobronchial secretions free from agents of the biofilm of the ETT, through the protected technique, would provide better results than culture for the diagnosis of VAP. Thus, the following inquiry arose: does the collection of TA by the protected technique, that is, without the aspiration probe itself entering in contact with the inner surface of the ETT, present a correlation with the traditional technique and is it safe for the patient? With the scope to investigate this doubt that emanated from clinical practice, and to provide advancements to confirm or refute TA using the protected technique, this investigation was proposed, which had as its objectives to evaluate the safety of the performance of traditional and protected collection techniques for TA and to identify the qualitative and quantitative agreement of the results of microbiological cultures between the techniques.

\section{METHOD}

This was a clinical, prospective, comparative, singleblind study. Data collection was conducted from January to September of 2013 , in a general ICU with adult patients in a university hospital in the state of Mato Grosso do Sul, Brazil. Purposive sampling was conducted, with inclusion of patients from the age of 18, undergoing invasive mechanical ventilation (MV) for a period of more than 48 hours and with suspected VAP; and the exclusion of those with pneumonia prior to the MV. The suspected pneumonia was determined by the treating physician and was based on the presence of at least two of the following criteria: leukocytosis $\left(>11,000\right.$ cells $/ \mathrm{mm}^{3}$ ) or leukopenia $\left(<4,000\right.$ cells $\left./ \mathrm{mm}^{3}\right)$, fever $\left(>38.4^{\circ} \mathrm{C}\right)$ or hypothermia $\left(<36.5^{\circ} \mathrm{C}\right)$, new or progressive infiltrate on chest radiograph and purulent tracheobronchial secretions ${ }^{(6)}$. The VAP was microbiologically defined, when the TA collected by the traditional technique reached a count $\geq 10^{5}$ colony forming units per millilitre (UFC/ml) $)^{(1)}$.

The study sample was composed of 54 patients who generated 80 pairs of microbiological samples - a mean of 1.5 collected per patient. Nine patients presented with suspected VAP more than one time during their stay in the ICU, therefore, their data were collected more than one time. The protected and traditional techniques were adopted for the same patient, one immediately after the other, conducted by a nurse, who was aided by a physiotherapist, both specialists in intensive care, experienced and trained for execution of the procedures.

The order of execution of the techniques in each patient were randomized, according to randomization software (http://www.randomization.com). Before the collection, the inspiratory fraction of oxygen $\left(\mathrm{FiO}_{2}\right)$ was increased to $100 \%$ for one minute and, during the procedures, arterial pressure, cardiac frequency, oxygen saturation via pulse oximetry and hemorrhages were monitored. In both techniques, an open suction system was used. It is emphasized that, a week before the sample collection, a pilot study was conducted with five patients for calibration of the procedures.

The collection of TA by the traditional technique was performed according to standard procedure, that is, using a 12 French (Fr) siliconized polyvinyl chloride (PVC)

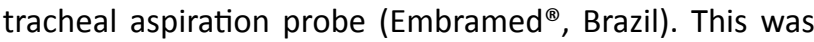
introduced through the ETT until resistance was encountered (level of the carina in the trachea), and retracted approximately $2 \mathrm{~cm}$. This was followed by the release of the vacuum and the probe was delicately removed using turning movements, from which the secretion was aspirated into a sterile polypropylene collector tube (bronco collector; Zammi ${ }^{\circledR}$, Brazil).

For the protected technique, a tracheal probe (\#10 Fr) and another nasogastric tube (\#20 Fr) were used, the latter being cut to a length $7 \mathrm{~cm}$ longer than that of the ETT. 
Subsequently, it was introduced into the ETT until it was 2 $\mathrm{cm}$ beyond the distal end of the tube, thereby being externalized $5 \mathrm{~cm}$ relative to the proximal end. Afterwards, the tracheal probe itself was introduced into the nasogastric tube, and secretions were aspirated (Figure 1). No saline solution was used for either sample to liquefy secretions, and strictly aseptic principles were followed.

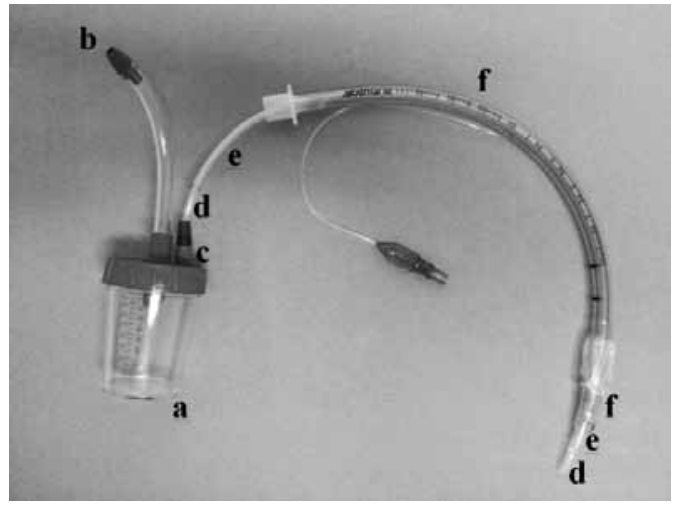

Figure 1 - Arrangement of the devices used in the collection of the TA by the protected technique: (a) Collection bottle; (b) Output for vacuum; (c) Entry of secretions; (d) Aspiration probe \#10 Fr; (e) thick probe \#20 Fr; (f) Orotracheal tube.

Following the microbiological collection, the samples were transported to the microbiology laboratory, in a time not exceeding 30 minutes, and were subjected to identical microbiological and blinded processing, that is to say, without the lab staff knowing by which technique the samples were collected. Only samples with less than 25 epithelial cells per field (100x magnification) were considered, and they were processed as suggested by the protocol Cumitech $7 B$ of the American Society for Microbiology ${ }^{(7)}$.

The tracheal secretion (the most purulent portion), therefore, was liquefied with the addition of an equal volume of $1 \% \mathrm{~N}$-acetyl cysteine and subsequent homogenization (Vortex Mod QL-901-BIOMIXE ${ }^{\circledR}$ ) for one minute at $3,000 \mathrm{rpm}$. Subsequently, a $0.1 \mathrm{ml}$ sample was diluted in $9.9 \mathrm{ml}$ sterile physiological solution; $0.01 \mathrm{ml}$ was seeded (calibrated loop) in Petri dishes containing MacConkey agar, blood agar azide and chocolate agar. Incubation of the dishes was performed in aerobiosis at $35 \pm 1$ o $C$ for 24 to $48 \mathrm{~h}$, except for the chocolate agar, in capnofilia (5\% of $\mathrm{CO}_{2}$ ) at $35 \pm 1$ o $\mathrm{C}$ for 24 to $48 \mathrm{~h}$. The first quantitative reading was performed after 24 hours and, in cases of difficult macroscopic differentiation or absence of colonies, re-incubated for another $24 \mathrm{~h}^{(7)}$.

In the interpretation of results, each colony corresponded to $20,000 \mathrm{CFU} / \mathrm{ml}$, and it was considered to be TA positive when the count was $\geq 10^{5} \mathrm{CFU} / \mathrm{ml}^{(1)}$. The identification of the microorganism was performed by means of the automation device, Vitek ${ }^{\circledast} 2$ AES (BioMérieux, France). The ethical precepts of Resolution No. 466/12 of the National Health Council were respected, and the institutional Committee on Ethics in Research (CER) with

human beings approved the project, under protocol number 114311/2012.

Data were stored in the Microsoft Excel software, 2010 version, and statistically analyzed using Minitab for Windows (version 14). In addition to descriptive statistics, the chi-square $\left(\chi^{2}\right)$ and Fisher exact tests, both with 95\% reliability (significant $p$ value $<0.05$ ), were used, and applied at the crossing of categorical variables.

\section{RESULTS}

The analysis involved 54 patients with suspected VAP who generated 160 samples for cultures (80 pairs, each with collection using the protected and traditional technique). The demographic and clinical characteristics of these patients are presented in Table 1.

Table 1- Demographic and clinical characteristics of the patients - Campo Grande, MS, Brazil, 2013

\begin{tabular}{|c|c|}
\hline Variables & $\begin{array}{l}\text { Results } \\
n^{\circ} \text { or mean }(\%) \pm \text { SD }\end{array}$ \\
\hline Subjects (n) & 54 \\
\hline Age (years) & $63.8 \pm 17.5$ \\
\hline \multicolumn{2}{|l|}{ Sex } \\
\hline Masculine & $31(57.4)$ \\
\hline Feminine & $23(42.6)$ \\
\hline Days spent in hospital (days) & $19 \pm 9.8$ \\
\hline Days of hospitalization in ICU (days) & $11 \pm 9.2$ \\
\hline \multicolumn{2}{|l|}{ Origin } \\
\hline Emergency Room & $34(63)$ \\
\hline Clinical Medicine & $11(20.4)$ \\
\hline Clinical Surgery & $6(11.1)$ \\
\hline Other & $3(5.5)$ \\
\hline Time on MV (hours) & $314 \pm 208.6$ \\
\hline \multicolumn{2}{|l|}{ Comorbidities } \\
\hline $\mathrm{SAH}$ & $34(63)$ \\
\hline $\mathrm{DM}$ & $19(35.2)$ \\
\hline Infectious-Parasitic Diseases & $15(27.8)$ \\
\hline $\mathrm{CHF}$ & $14(25.9)$ \\
\hline Neurological injuries & $11(20.4)$ \\
\hline Digestive injuries & $11(20.4)$ \\
\hline COPD & $8(14.8)$ \\
\hline CRI & $6(11.1)$ \\
\hline Câncers & $3(5.6)$ \\
\hline APACHE II on admission & $24,8 \pm 5.4$ \\
\hline Use of antimicrobials & $54(100)$ \\
\hline \multicolumn{2}{|l|}{ Pharmacological class } \\
\hline Antibacterials & $52(96.3)$ \\
\hline Carbapenemics & $38(70.4)$ \\
\hline Penicillins & $31(57.4)$ \\
\hline Glycopeptides & $29(53.7)$ \\
\hline Macrolides & $26(48.1)$ \\
\hline Polymyxins & $24(44.4)$ \\
\hline Aminoglycosides & $15(27.8)$ \\
\hline Fluoroquinolones & $11(20.4)$ \\
\hline Cephalosporins & $10(18.5)$ \\
\hline Antifungals & $24(44.5)$ \\
\hline Triazoles & $18(33.3)$ \\
\hline
\end{tabular}




\begin{tabular}{|c|c|}
\hline \multicolumn{2}{|l|}{... Continuation } \\
\hline Variables & $\begin{array}{l}\text { Results } \\
\text { n }^{\circ} \text { or mean }(\%) \pm \text { SD }\end{array}$ \\
\hline Echinocandins & $11(20.4)$ \\
\hline Polyenes & $5(9.3)$ \\
\hline Time on antibiotic therapy (days) & $16.2 \pm 13.1$ \\
\hline \multicolumn{2}{|l|}{ White blood count } \\
\hline Leukocytes $\left(\right.$ cell $\left./ \mathrm{mm}^{3}\right)$ & $19.654 \pm 17.268$ \\
\hline Neutrophils (\%) & $79.3 \pm 15.3$ \\
\hline Rods (\%) & $18.5 \pm 11.6$ \\
\hline Lymphocytes (\%) & $8.2 \pm 5.1$ \\
\hline Temperature $\left({ }^{\circ} \mathrm{C}\right)$ & $37.4 \pm 0.6$ \\
\hline \multicolumn{2}{|l|}{ Aspect of the tracheal secretions } \\
\hline Mucoid & $43(79.6)$ \\
\hline Purulent & $11(20.4)$ \\
\hline \multicolumn{2}{|l|}{ Discharge from the ICU } \\
\hline Death & $30(55.6)$ \\
\hline Discharge & $21(38.9)$ \\
\hline Transfer & $3(5.5)$ \\
\hline \multicolumn{2}{|c|}{$\begin{array}{l}\text { Note: SAH: Systemic arterial hypertension; DM: Diabetes Mellitus; } \\
\text { CHF: Congestive Heart Failure; COPD: Chronic Obstructive } \\
\text { Pulmonary Disease; CRI: Chronic Renal Insufficiency; APACHE II: Acute } \\
\text { Physiology and Chronic Health Evaluation. }\end{array}$} \\
\hline
\end{tabular}

Globally, the majority of the patients were male; of advanced age; with many days of hospitalization and MV; originating from the emergency room; affected by different comorbidities; and with a high estimated mortality score by the APACHE II, which led to the outcome of deaths in the

majority of the subjects; increased number of leukocytes and rods; normothermic; and all were on antibiotic therapy.

Considering the microorganism and $\mathrm{CFU} / \mathrm{ml}$, when the techniques were implemented in the same patient, one immediately after the other, the correlation between these was statistically significant (Table 2).

Table 2 - Agreement between the analyzed techniques, according to microorganism isolated and UFC/ml - Campo Grande, MS, Brazil, 2013

\begin{tabular}{|c|c|c|c|c|c|c|c|}
\hline \multirow{2}{*}{\multicolumn{2}{|c|}{$\underset{\text { CFC } / \mathrm{ml}}{\text { Microrganism } x}$}} & \multicolumn{2}{|c|}{$\begin{array}{c}\text { Agreement } \\
\text { CFU/ml }\end{array}$} & \multicolumn{3}{|c|}{ Odds Ratio } & \multirow[t]{2}{*}{$\mathbf{P}^{*}$} \\
\hline & & Yes & No & Estimate & Lower & Upper & \\
\hline \multirow{2}{*}{$\begin{array}{c}\text { Agreement } \\
\text { Microrganism }\end{array}$} & Yes & 58 & 6 & \multirow{2}{*}{54.13} & \multirow{2}{*}{11.54} & \multirow{2}{*}{253.98} & \multirow{2}{*}{$<0,001$} \\
\hline & $\mathrm{No}$ & 3 & 13 & & & & \\
\hline
\end{tabular}

When the results of culture isolates were revealed as identical or absent in both the techniques, this was interpreted as concordance of the microorganism - regardless of the count; and agreement of the $\mathrm{CFU} / \mathrm{ml}$ when there was an identical count $<10^{5}$ or $\geq 10^{5}$ for both techniques. Table 2 presents the agreement resulting from the crossing of these variables. It was perceived that, of the 80 pairs of samples, 58 presented the same microorganism and CFU/ml simultaneously. Therefore, the overall agreement between the protected and traditional technique was $72.5 \%(p<0.001)$.

Table 3 - Comparison of the tracheal aspirate cultures collected using protected and traditional technique. Campo Grande, MS, Brazil, 2013

\begin{tabular}{|c|c|c|c|}
\hline \multirow{2}{*}{ Result } & \multirow{2}{*}{$\begin{array}{l}n^{0} .(\%) \\
\text { episodes }\end{array}$} & \multicolumn{2}{|c|}{ Microrganism(s) recovered } \\
\hline & & Protected technique & Traditional technique \\
\hline 1 & $44(55)$ & Identical & Identical \\
\hline 2 & $20(25)$ & None & None \\
\hline 3 & $2(2.5)$ & None & Candida albicans \\
\hline 4 & $1(1.25)$ & None & Klebsiella pneumoniae \\
\hline 5 & $1(1.25)$ & Acinetobacter baumanii & None \\
\hline 6 & $1(1.25)$ & Pseudomonas aeruginosa & None \\
\hline 7 & $1(1.25)$ & $\begin{array}{l}\text { Pseudomonas aeruginosa } \\
\text { Candida albicans }\end{array}$ & $\begin{array}{c}\text { Pseudomonas aeruginosa } \\
-\end{array}$ \\
\hline 8 & $1(1.25)$ & $\begin{array}{c}\text { Candida albicans } \\
\text { Staphyloccus epidermidis } \\
\text { Pseudomonasaeruginosa }\end{array}$ & $\begin{array}{c}\text { Candida albicans } \\
\text { Staphyloccus epidermidis }\end{array}$ \\
\hline 9 & $1(1.25)$ & $\begin{array}{c}\text { Candida tropicalis } \\
\text { Pseudomonas aeruginosa }\end{array}$ & Candida tropicalis \\
\hline 10 & $1(1.25)$ & $\begin{array}{l}\text { Acinetobacter baumanii } \\
\text { Staphyloccus epidermidis }\end{array}$ & $\begin{array}{c}\text { Acinetobacter baumanii } \\
-\end{array}$ \\
\hline 11 & $1(1.25)$ & $\begin{array}{l}\text { Candida albicans } \\
\text { Klebsiella pneumoniae } \\
\text { Enterococcus faecium }\end{array}$ & $\begin{array}{c}\text { Candida albicans } \\
- \\
-\end{array}$ \\
\hline 12 & $1(1.25)$ & $\begin{array}{c}\text { Staphylococcus aureus } \\
\text { Stenotrophomonas maltophilia }\end{array}$ & Staphylococcus aureus \\
\hline 13 & $1(1.25)$ & $\begin{array}{c}\text { Pseudomonas aeruginosa } \\
\text { Klebsiella pneumoniae } \\
\text { Stenotrophomonas maltophilia } \\
\text { Staphylococcus cohnii } \\
-\end{array}$ & $\begin{array}{c}\text { Pseudomonas aeruginosa } \\
- \\
- \\
- \\
\text { Staphylococcus warneri }\end{array}$ \\
\hline 14 & $1(1.25)$ & $\begin{array}{c}\text { Staphylococcus aureus } \\
-\end{array}$ & $\begin{array}{l}\text { Staphylococcus aureus } \\
\text { Klebsiella pneumoniae }\end{array}$ \\
\hline 15 & $1(1.25)$ & $\begin{array}{c}\text { Pseudomonas aeruginosa } \\
-\end{array}$ & $\begin{array}{l}\text { Pseudomonas aeruginosa } \\
\text { Klebsiella pneumoniae }\end{array}$ \\
\hline
\end{tabular}




\begin{tabular}{|c|c|c|c|}
\hline \multicolumn{4}{|c|}{... Continuation } \\
\hline \multirow{2}{*}{ Result } & \multirow{2}{*}{$\begin{array}{l}\mathrm{n}^{0} .(\%) \\
\text { episodes }\end{array}$} & \multicolumn{2}{|c|}{ Microrganism(s) recovered } \\
\hline & & Protected technique & Traditional technique \\
\hline 16 & $1(1.25)$ & $\begin{array}{c}\text { Pseudomonas aeruginosa } \\
\text { Acinetobacter baumanii } \\
-\end{array}$ & $\begin{array}{l}\text { Pseudomonas aeruginosa } \\
\text { Acinetobacter baumanii } \\
\text { Staphylococcus hominis }\end{array}$ \\
\hline 17 & $1(1.25)$ & $\begin{array}{c}\text { Candida parapsilosis } \\
- \\
- \\
-\end{array}$ & $\begin{array}{c}\text { Candida parapsilosis } \\
\text { Pseudomonas aeruginosa } \\
\text { Acinetobacter baumanii } \\
\text { Elizabethkingia meningoseptica }\end{array}$ \\
\hline
\end{tabular}

According to Table 3, considering only the isolated microorganism, regardless of a count lower or higher than $10^{5} \mathrm{CFU} / \mathrm{ml}$, it was verified that there was complete concordance between both techniques in $80 \%$ of the episodes of suspected VAP (results 1 and 2). In five episodes (6.25\%), there were completely discordant results - negative microbial culture for one of the techniques and positive for the other. In three episodes (results 3 and 4 ) there was no retrieval of agents when the protected technique was performed; while for the traditional technique, in two episodes (results 5 and 6) the same situation occurred. In all other cases, the results were quite varied, with isolation of extra microorganisms occurring (additional strains found in one technique, but not the other), both in the protected technique (outcomes $7,8,9,10,11,12$ and 13) as well as the traditional (results 13,14,15, 16 and 17). It is noteworthy that $70 \%(7 / 10)$ of the identified extra microorganisms in the protected technique had a count less than $10^{5} \mathrm{CFU} / \mathrm{ml}$, as compared to $42.9 \%(3 / 7)$ of the traditional technique $(p<0.05)$.

In relationship to the safety of the two techniques, there were no statistically significant adverse events $(p<0.05)$ such as oxygen desaturation, hemodynamic instability or tracheobronchial hemorrhage.

\section{DISCUSSION}

In the search for improvements in the quality of collected samples of tracheal secretions, that is to say, those free from contamination, this study examined the correlation between two collection techniques of TA for microbiological diagnosis of VAP. The results suggest that there were no statistically significant differences $(p<0.001)$ between the techniques, both qualitatively (isolated microorganism) and quantitatively (CFU/ml).

Various extras microorganisms were isolated in both techniques. In this case, although the cultures derived from samples collected by the protected technique presented a higher percentage of extra agents, such as the count $<10^{5} \mathrm{CFU} / \mathrm{ml}$ ( $70 \%$ vs. $42.9 \%$ ), it is not prudent to assert that one technique was more accurate compared to the other for the diagnosis of VAP, because there is no concept that distinguishes contamination from colonization in tracheal secretions. It was therefore not possible to distinguish whether these extra agents were microorgan- isms of the biofilm of the ETT or colonized from the lung parenchyma $^{(6)}$. One of the possible alternatives would be to analyze genetically, by polymerase chain reaction or a compatible method, the extra microorganisms isolated in the protected and traditional technique with those present in the ETT biofilm.

Taking into consideration only the extra isolates with a count $<10^{5} \mathrm{CFU} / \mathrm{ml}$, and using a classification proposed by an extensive literature review ${ }^{(8)}$, in the protected technique four (57.1\%) agents were common causes of $\operatorname{VAP}(P$. aeruginosa, $2 K$. and E. faecium), one (14.3\%) rarely provoked a referred infection (S. maltophilia) and two $(28.6 \%)$ were not important epidemiological causes (S. cohnii and S. epidermidis). Whereas in the traditional technique, two (66.7\%) were common causes of VAP (P. aeruginosa and $A$. baumannii) and one (33.3\%) was not causative ( $S$. hominis). This further complicates the definition of which technique is more reliable, because, of course, some of these agents may be contaminants, however, they may also be colonizers with the potential to develop and cause infections.

To demonstrate this, using surveillance cultures of TA, a prospective cohort ${ }^{(9)}$, that included 200 patients, had as one of its objectives to identify the colonizers of pulmonary parenchyma and their respective ability to evolve and, later, to cause VAP. According to the results, the majority $(60.9 \%$; $14 / 23)$ of the causative microorganisms of VAP were initially present as colonizers of the pulmonary parenchyma. The rates of colonization following the later development of VAP were relative higher for nonfermenting bacterias $(46.4 \%)$, methicillin-resistant $S$. aureus (33.3\%) and Enterobacteriaceae(22.2\%).

In any case, these results contradict the expectation that the protected technique recovers a lower quantity of extra microorganisms, since it avoids the contact of the aspiration tube itself with the microorganisms present in the biofilm of the ETT, and thereby prevents what is collected, cultivated and falsely released as pathogens of the pulmonary tissue.

The primary reason that may have contributed to this finding is that these extra microorganisms may have colonized pulmonary tissue, since the genetic correlation with those of the ETT biofilm was not studied. The second is related to the fact that the intubated patient is subjected to various daily endotracheal aspirations. This

\section{Rev Esc Enferm USP \\ $2014 ; 48(4): 618-24$ \\ www.ee.usp.br/reeusp/}

Collection of tracheal aspirate: safety and microbiological concordance between two techniques Frota $O P$, Ferreira $A M$, Barcelos $L S$, Watanabe $E$, Carvalho NCP, Rigotti MA 
can result in dissemination of biofilm agents towards the lower airways, and vice versa. From this perspective, the TA collected by the protected and traditional technique would not differ as to the presence or absence of organisms from ETT. The third is that the thicker probe may have caused friction to the internal wall of the ETT and dislocated biofilm microorganisms to the lower airways, as well as to its own distal or inner surface and, subsequently, all of this material was collected by the aspiration probe.

Whether these are the real reasons that led to the results encountered or not, the fact is that the protected technique showed statistically significant agreement in relation to the traditional and, safeguarding the limitations of the study, showed no significant benefits. Given this result, we do not recommend the use of the technique, considering this is potentially capable of increasing hospital costs, since it demands a longer collection time, requires specific materials in relationship to the traditional and that, if agents actually include the biofilm of the ETT in the samples, it can lead to errors of interpretation or false positive results or undue changes in antibiotic therapy.

It is noteworthy that, after three days of intubation and MV, the lumen of the ETT became heavily colonized by various microorganisms. These move on to survive on the abiotic surface of the tube in the form of mature biofilm, that is, in a structured system of communities, coordinated and functional with a high degree of organization ${ }^{(10)}$. Studies have shown that the occurrence of VAP and other infection in the lower respiratory tract can be a consequence of the recurring transference of agents present in this biofilm to the lower airways ${ }^{(5,10-12)}$. A recent randomized clinical controlled trial $^{(10)}$ found that more than $60 \%$ of patients had isolates of the same species in both the biofilm of the ETT as well as in the bronchial secretion, and the tip of the ETT was the region with the highest density of pathogens associated with VAP.

As yet there is no gold standard for the microbiological diagnosis of $\operatorname{VAP}^{(13)}$ and the problems related to the excessive use of antibiotics and antimicrobial resistance continue to grow; improving the accuracy of microbiological diagnosis of VAP becomes an essential element for ensuring adequate antibiotic coverage for Multi-Drug Resistant Organism (MDRO), and to limit the use and duration of empirically prescribed broad spectrum antibiotic therapy. In the context of the use of quantitative culture techniques, collecting tracheal secretions stands out as crucial step for a precise and accurate diagnosis ${ }^{(14)}$. On the other hand, the biofilm of the ETT is a variable that can adversely impact this process.

It is widely recommended that the collection of any type of biological material for culture should occur in the absence of antibiotic therapy, since the previous use of antibiotics can cause false negative results. In the case of cultures of tracheobronchial secretions, this has been a problem for both clinical practice as well as research because, depending on the profile of the ICU patients, the vast majority of those with suspected VAP are seriously ill and have also been subjected to various procedures and treatments, many of which have the potential to propitiate or develop clinical changes typical of infection. Sometimes, many patients receive antibiotics before the suspicion of VAP; some, before arriving in intensive care ${ }^{(14)}$.

In this study, $100 \%$ of the patients were using antimicrobials - many of broad spectrum (Table 1 ). This could be a limitation, therefore, especially considering the increase in the rates of nosocomial infections, the emergence of MDRO strains, pressure suffered by the physician for the early initiation of antibiotic therapy, the state in which the patient is found when there is the suspicion of VAP, and antibiotic use in ICU for nonpneumonic causes. It is believed that the results of this study are valid, they correspond to the current national and international health scenario, and it is not advantageous to conduct studies in a reality that is different from the current one.

Although recommended in some documents ${ }^{(7,15)}$, it is noteworthy that $0.9 \%$ saline was not instilled to facilitate the collection of secretions, because it would compromise the comparison between techniques. Furthermore, if the results are expressed in $\mathrm{CFU} / \mathrm{ml}$, the aforementioned practice turns into an unstable mathematical relationship, since the amount of fluid instilled and later retrieved is variable. For example, if only a small volume of liquid is recovered by aspiration, then, the bacteria count may be mistakenly larger due to the smaller volume of diluent. On the other hand, if a larger volume of liquid is recovered, the concentration will be lower at the expense of increased dilution ${ }^{(2)}$.

Although the implementation of the protected technique occluded more than $50 \%$ of the lumen of the ETT, it is important to stress that no iatrogenic complications of an oxy-hemodynamic order were observed between the relevant techniques, even hemorrhage. It was inferred that the latter would be one of the possible complications related to the protected technique, since the outer tube was not blunted and was relatively thicker and more rigid than traditional aspiration probes. Only one patient had bleeding during collection, but this was unrelated to the protected technique because the hemorrhaging started during the execution of the traditional technique (the first to be performed on the patient, according to randomization). Furthermore, the patient showed severe changes in blood clotting and invariably bled during routine endotracheal aspiration procedures.

This study had several limitations, including the nonprobabalistic sample, not including other diagnostic 
methods for VAP - such as bronchoalveolar lavage - in order to compare the results of cultures between the TA techniques and not to analyze by means of tests the genotyping assays of agreement between the recovered microorganisms in both the techniques possible with the biofilm of the ETT.

However, despite these limitations, this is the first study to our knowledge that focused on comparative analysis of the tracheal aspirate using the traditional versus protected method. The findings of this study raise an important issue, potentially able to interfere with the quality of the results of the tracheal aspirate culture to support the diagnosis of VAP, suggesting the need for further discussions and reflections through robust and welldesigned research.

\section{REFERENCES}

1. Shin YM, Oh YM, Kim MN, Shim TS, Lim CM, Lee SD, et al. Usefulness of quantitative endotracheal aspirate cultures in intensive care unit patients with suspected pneumonia. J Korean Med Sci. 2011;26(7):865-9.

2. Fujitani S, Yu VL. Quantitative cultures for diagnosing ventilator-associated pneumonia: a critique. Clin Infect Dis. 2006;43 Suppl 2:S106-13.

3. Niederman MS. The argument against using quantitative cultures in clinical trials and for the management of ventilatorassociated pneumonia. Clin Infect Dis. 2010;51Suppl 1:S93-9.

4. Zolfaghari PS, Wyncoll DL. The tracheal tube: gateway to ventilator-associated pneumonia. Crit Care [Internet]. 2011 [cited 2014 Feb 22];15(5):310. Available from: http://www. ncbi.nlm.nih.gov/pmc/articles/PMC3334734/

5. Gil-Perotin S, Ramirez P, Marti V, Sahuquillo JM, Gonzalez E, Calleja I, et al. Implications of endotracheal tube biofilm in ventilator-associated pneumonia response: a state of concept. Crit Care [Internet]. 2012 [cited 2014 Feb 22];16(3):R93. Available from: http://www.ncbi.nlm.nih.gov/pmc/articles/ PMC3580639/

6. Khilnani GC, Arafath TL, Hadda V, Kapil A, Sood S, Sharma SK. Comparison of bronchoscopic and non-bronchoscopic techniques for diagnosis of ventilator associated pneumonia. Indian J Crit Care Med. 2011;15(1):16-23.

7. Sharp SE, Robinson A, Saubolle M, Cruz MS, Carroll K, Baselski V. Cumitech 7B: lower respiratory tract infections. Washington: American Society for Microbiology; 2004.

8. Joseph NM, Sistla S, Dutta TK, Badhe AS, Parija SC. Ventilatorassociated pneumonia: a review. Eur J Intern Med. 2010;21(5):360-8.

\section{CONCLUSION}

We conclude that the tested techniques are statistically equivalent, as to the quantity and quality of recovered microorganisms. They are safe for the patient, because relevant iatrogenic complications of an oxy-hemodynamic and hemorrhagic order were not found. Extra microorganisms were found in both techniques. These are potentially capable of interfering in the quality of the results of microbiological culture and leading to adverse effects in the management of antibiotics, with the potential for inadequate or excessive treatment. However, it was not possible to distinguish whether these results represent microorganisms present in the biofilm of the ETT, in the lower respiratory tract, or in both.

9. Joseph NM, Sistla S, Dutta TK, Badhe AS, Parija SC. Ventilatorassociated pneumonia: role of colonizers and value of routine endotracheal aspirate cultures. Int J Infect Dis. 2010;14(8):e723-9.

10. Liu W, Zuo Z, Ma R, Zhang X. Effect of mechanical cleaning of endotracheal tubes with sterile urethral catheters to reduce biofilm formation in ventilator patients. PediatrCrit Care Med. 2013;14(7):338:43.

11. Berra L, Coppadoro A, Bittner EA, Kolobow T, Laquerriere $P$, Pohlmann JR, et al. A clinical assessment of the Mucus Shaver: a device to keep the endotracheal tube free from secretions. Crit Care Med. 2012;40(1):119-24.

12. Souza PR, Andrade D, Cabral DB, Watanabe E. Endotracheal tube biofilm and ventilator-associated pneumonia with mechanical ventilation. Microsc Res Tech. 2014;77(4):305-12.

13. Charles MP, Easow JM, Joseph NM, Ravishankar M, Kumar $\mathrm{S}$, Umadevi $\mathrm{S}$. Incidence and risk factors of ventilator associated pneumonia in a tertiary care hospital. Australas Med J. 2013;6(4):178-82.

14. Fujitani S, Cohen-Melamed MH, Tuttle RP, Delgado E, Taira Y, Darby JM. Comparison of semi-quantitative endotracheal aspirates to quantitative non-bronchoscopicbronchoalveolar lavage in diagnosing ventilator-associated pneumonia. Respir Care. 2009;54(11):1453-61.

15. Mourani PM, Harris JK, Sontag MK, Robertson CE, Abman $\mathrm{SH}$. Molecular identification of bacteria in tracheal aspirate fluid from mechanically ventilated preterm infants. PLoS One. 2011;6(10):e25959.
Correspondence addressed to: Adriano Menis Ferreira Av. Ranulpho Marques Leal, 3220 - Distrito Industrial CEP 79610-100 - Três lagoas, MS, Brazil E-mail: a.amr@ig.com.br 